\title{
ENSO-induced groundwater changes in India derived from GRACE and GLDAS
}

\author{
Naresh Krishna Vissa*, P C Anandh, Mama Manjali Behera and \\ SAMEEKSHA Mishra \\ Department of Earth and Atmospheric Sciences, National Institute of Technology Rourkela, \\ Sundargarh, Odisha 769 008, India. \\ *Corresponding author.e-mail: vissan@nitrkl.ac.inｖissanaresh@gmail.com
}

MS received 3 October 2018; revised 11 December 2018; accepted 17 December 2018; published online 8 May 2019

This study aims to quantify the interannual variations of groundwater storage changes (GWSCs) over India. GWSCs are derived from the gravity recovery and climate experiment (GRACE) and global land data assimilation system (GLDAS)-Noah life safety model (LSM) for the period 2003-2015. Estimated GWSCs are validated with the satellite altimetry over the six lake stations. The variability of GWSC and altimetry water-level heights are assessed with the cross-correlation and plotting analysis. Annual trends of GWSC and GRACE in terrestrial water storage (TWS) were estimated using the non-parametric Mann-Kendall test and Sen's slope method. Results suggest that GWSC and TWS have declined in northern India at the rate of $\sim 1.6 \mathrm{~cm} \mathrm{yr}^{-1}$ and in southern and western central India at the rate of $\sim 0.5 \mathrm{~cm} \mathrm{yr}^{-1}$. Impacts of short-term climate perturbations such as El Niño and La Niña for the GWSCs are assessed. During the El Niño period, the decline of GWSC over northern India enhanced, whereas during the La Niña period, the recovery of GWSC is evident. These interannual variations of GWSCs over India are attributed by interannual precipitation changes. Under the global warming scenario, the occurrences of El Niño events are likely to enhance in the future, and our findings help the water resource management policy makers for necessary actions during such short-term climate perturbations.

Keywords. Groundwater; ENSO; GRACE; climate change; India.

\section{Introduction}

Groundwater will play an important role in adaptation to climate variability having wide socioeconomic implications and vulnerable to unchecked rates of extraction and climate change (Chinnasamy et al. 2013; Taylor et al. 2013a; Bhanja et al. 2017). The usage and availability of groundwater information are crucial for future water management and strategic reserve during periods of drought (Famiglietti 2014; Richey et al. 2015). The launch of the gravity recovery and climate experiment (GRACE) during the year 2002 revolutionised the capacity in understanding the groundwater changes around the globe for practical purposes (Swenson et al. 2003, 2006; Chen et al. 2014; Lakshmi 2016; Girotto et al. 2017; Mukherjee and Ramachandran 2018; Rodell et al. 2018). Previous studies have reported the rapid depletion of groundwater throughout the tropics and subtropics using in-situ and GRACE measurements (Rodell et al. 2009, 2018; Panda and Wahr 2016; Asoka et al. 2017).

Global sea surface temperatures and sea-level pressure patterns play a significant role in climate variability, which show an important role in the 
hydro-climatology of the basin considerably such as temperature, precipitation and streamflow. Substantial evidence exists on the relationship between the teleconnections [e.g., El Niño/southern oscillation (ENSO), Indian Ocean dipole (IOD) and Pacific decadal oscillation (PDO)] and its effects on regional/headwaters precipitation, temperature and streamflow (Devineni and Sankarasubramanian 2010; Almanaseer and Sankarasubramanian 2011; Taylor et al. 2013b; Krishnaswamy et al. 2015). Therefore, it is important to develop a conceptual understanding of the relationship between groundwater and interannual and multi-decadal climate variables. Recent studies have explored the relationship between groundwater and climate variability. Over the Nile basin, GRACE-derived groundwater changes indicate a significant relationship with climate variability (Ouma et al. 2015). Similarly, over the North China Plain (Cao and Zheng 2016), Australian continent (Han 2017), the United States of America (Almanaseer and Sankarasubramanian 2011; Kuss and Gurdak 2014; Russo and Lall 2017) studies indicate a strong relationship between groundwater changes and climate variability. Recently $\mathrm{Ni}$ et al. (2018) noted over tropical and subtropical regions the changes in terrestrial water storage (TWS) during ENSO events are significant.

Previous studies have attempted to quantify groundwater changes over the Indian subcontinent using satellite-derived products and in-situ measurements. Over the northwest Indian region, groundwater depletion of $4 \pm 1 \mathrm{~cm} \mathrm{yr}^{-1}$ was reported for the period 2002-2008, whereas no change in annual rainfall is evident during that period (Rodell et al. 2009). Over northern India, Tiwari et al. (2009) reported a decrease of water storage about $2 \mathrm{~cm} \mathrm{yr}^{-1}$ for the period 20022008. Over southern India, GRACE total water storage shows a positive trend for the period 20022012 (Tiwari et al. 2009). Using GRACE satellite data spatio-temporal evolution of water storage changes revealed that over the northern parts of India, substantial groundwater depletion of 1.25 and $2.1 \mathrm{~cm} \mathrm{yr}^{-1}$ was reported for the Ganga basin and Punjab state, respectively (Panda and Wahr 2016). Chen et al. (2014) performed a linear trend analysis of GRACE-derived groundwater changes, with results indicating a depletion of $2.4 \mathrm{~cm} \mathrm{yr}^{-1}$ over the northwest India. Asoka et al. (2017) analysed long-term local well data and GRACE satellite data, their findings suggesting that changes in groundwater are linked to the relative contribution of monsoon precipitation. Considering profound implications on climate variability and the hydrological water cycle over the Indian subcontinent, the present study aims to understand the relationship between the ENSOinduced groundwater changes using GRACE satellite data. To ensure accuracy, satellite-derived groundwater changes are also validated with satellite altimetry water-level data over six different lakes in the Indian subcontinent.

\section{Materials and methods}

\subsection{Study area}

The study region comprises geographical boundaries surrounding the $5-35^{\circ} \mathrm{N}$ and $60-90^{\circ} \mathrm{E}$, which covers the Indian subcontinent. Hydrogeology of the Indian region consists of different types of aquifer systems. The Indo-Gangetic plain is majorly dominated by unconsolidated sedimentary aquifers, whereas the southern province of the Indian region comprises fractured crystalline aquifer systems (Bhanja et al. 2016). We present India map with state boundaries and topography maps of six major lakes, where satellite altimetry water level data (figure 1) are indicated.

\subsection{Data}

The study uses the latest GRACE one-degree spatial and monthly equivalent water height (EWH) obtained from the National Aeronautics and Space Administration's (NASA) Jet Propulsion Laboratory (JPL) (https://grace.jpl.nasa.gov/) for the period 2003-2015. In the present study, we have used the gridded RL05 data sets retrieved from the spherical harmonics solutions of JPL (Landerer and Swenson 2012). GRACE release 5 is a better version than previously released products (Bettadpur 2007). Vertical levels of soil moisture (SM) data, a global land data assimilation system (GLADS) and a Noah land surface model with $1^{\circ} \times 1^{\circ}$ spatial resolution in near time (Ek et al. 2003; Rodell et al. 2004) were available from the Goddard Earth Sciences Data and Information Services Centre (GES DISC). Monthly and climatological rainfall was obtained from the Global Precipitation Climatological Centre (GPCC) (version 7) available from http://www. esrl.noaa.gov/psd/. The time series of ENVISAT 


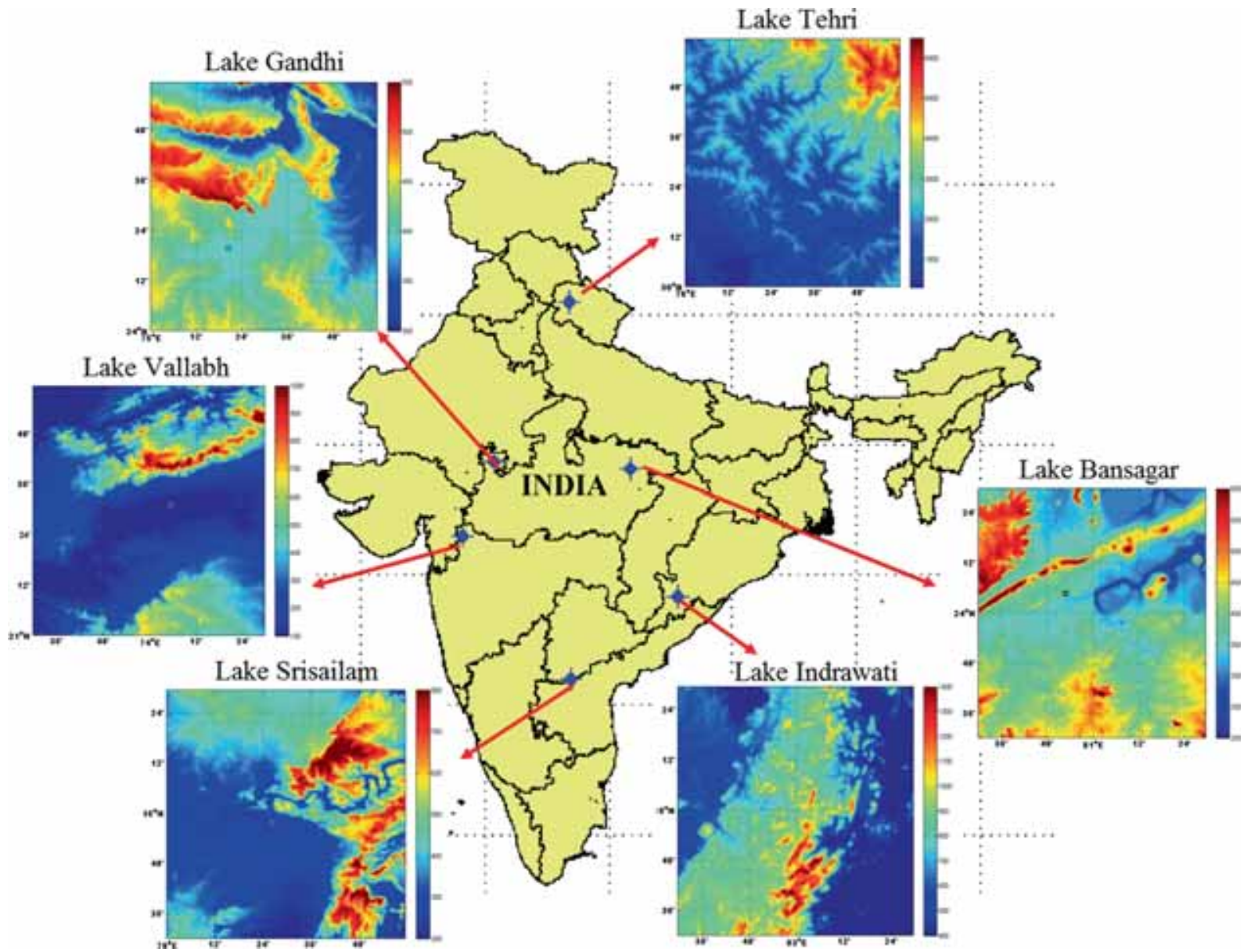

Figure 1. Locations of the six lakes (reservoirs) with topography over India map.

and Jason-1 altimetric water level variation over the six Indian lakes was obtained from the United States, Department of Agriculture (USDA) reservoir database available at (http://www.pecad.fas. usda.gov/cropexplorer/global_reservoir). A brief summary of data sets is described in table 1 . Hydrogeological information of the six lakes used in the present study was obtained from the report taken from the Central Ground Water Board, India (http://www.cgwb.gov.in/).

\subsection{Methodology}

\subsubsection{Estimation of groundwater storage changes (GWSC)}

Satellite-based GWSC are estimated from the water balance method using GRACE changes in TWS ( $\triangle$ TWS) and GLADS water content data (Rodell et al. 2009; Tiwari et al. 2009; Bhanja et al. 2016; Asoka et al. 2017). The mathematical expression for water balance method follows the relation

$$
\begin{aligned}
\Delta \mathrm{TWS}_{\mathrm{GRACE}}= & \Delta \mathrm{GWS}+\Delta \mathrm{SM}+\Delta \mathrm{SWE} \\
& +\Delta \mathrm{SW}+\Delta \mathrm{CWS},
\end{aligned}
$$

where $\Delta \mathrm{GWS}$ is the GWSC, $\Delta \mathrm{SM}$ is the change in soil moisture, $\triangle \mathrm{SWE}$ is the change in snow-water equivalent, $\Delta \mathrm{SW}$ represents the change in surface water storage and $\Delta \mathrm{CWS}$ signifies the changes in canopy water storage.

In order to estimate the GWSC, the anomalies of the soil moisture, snow-water equivalent and canopy water storage would be subtracted from the $\Delta$ TWS. The hydrological outputs of NASA Noah land surface model provide the total SM, SWE and CWS. Thus, GLADS water content can be expressed as

$$
\Delta \mathrm{GLDAS}=\Delta \mathrm{SM}+\Delta \mathrm{SWE}+\Delta \mathrm{CWS} .
$$

Subsequently, using equations (1 and 2) we can estimate the GWSC:

$$
\Delta \mathrm{GWS}=\Delta \mathrm{TWS}_{\mathrm{GRACE}}-\Delta \mathrm{GLDAS} .
$$


Table 1. Summary of the data sets used in the present study.

\begin{tabular}{lllccc}
\hline Data set & \multicolumn{1}{c}{ Product } & Units & $\begin{array}{c}\text { Spatial } \\
\text { resolution }\end{array}$ & $\begin{array}{c}\text { Temporal } \\
\text { resolution }\end{array}$ & $\begin{array}{c}\text { Observation } \\
\text { period }\end{array}$ \\
\hline GRACE & JPL level 3 TWS & $\mathrm{cm}$ & $1^{\circ}$ & Monthly & $2003-2015$ \\
GLDAS & NOAH soil moisture & $\mathrm{kg} / \mathrm{m}^{2}$ & $1^{\circ}$ & Monthly & $2003-2015$ \\
Jason-2 & Lake water level & $\mathrm{cm}$ & - & $\sim$ Weekly & $2008-2015$ \\
GPCC & Precipitation & $\mathrm{cm}$ & $0.5^{\circ}$ & Monthly & $2003-2015$ \\
\hline
\end{tabular}

\subsubsection{GWSC linked with inter-annual oscillations}

Teleconnections such as El Niño and La Niña could influence the hydrology of the region linked with the spatial heterogeneity of topography and hydrogeology (Taylor et al. 2013a, b; Krishnaswamy et al. 2015; Katpatal et al. 2018). In this study, the variations in the GWSC are also considered in relation to years when the following phenomena dominate, viz., El Niño and La Niña. The identification of such years a priori was obtained from the National Weather Service Climate Prediction Centre when concerning the El Niño, La Niña years based on the Oceanic Nino Index. (http://origin.cpc.ncep.noaa. gov/products/analysis_monitoring/ensostuff/ONI_ v5.php).

\subsubsection{Non-parametric Mann-Kendall (MK) test}

Monthly time series of GWSC and TWS was used to perform the statistical significance of the trend analysis based on the non-parametric MK test (Mann 1945; Sen 1968) for the period 2003-2015. MK is the widely used method to determine the statistical trend analysis for hydrological, precipitation and groundwater with reference to climate change (Kumar et al. 2010; Asoka et al. 2017). Trends signify the statistical significance at the $95 \%$ confidence level $(p<0.05)$, analysis was carried for the sample sizes: annual (156), El Niño (41) and La Niña (38).

\section{Results and discussion}

\subsection{Validation of satellite-derived GWSC}

Monthly water-level height and GWSC variations and cross-plotting of the six lakes (reservoirs) for the period 2008-2015 are shown in figure 2 . Over the lakes Gandhi, Indrawati, Vallabh (Srisailam) and Bansagar maximum peak of GWSC and water-level heights are evident during the years 2011 and 2013 (2010 and 2015) Indian summer monsoon months, whereas minimum peaks are evident during 2009 and 2015. Over the Tehri region, changes of GWSC and lake water level heights are inconsistent. Lake Tehri is a hilly region composed of mountain peaks, gorges and deep valleys and the hydrogeological formations of the study region do not support the ground water replenishment even though rainfall occurs through the year as either rainfall or snow. However, the overall reservoir water level and GWSC variations are in concurrence with the Indian summer monsoon drought and normal monsoon years (Sinha et al. 2017).

The cross-correlation of GWSC and lake water level height is shown in figure 3. For both parameters, the maximum correlation was seen over the Vallabh region $(\sim 0.8)$ with a lag of 1 month. Over the Bansagar Lake, no lag was seen between both parameters, whereas over the Tehri Lake, no significant relationship is evident. Correlation and lag between the GWSC and water-level height are associated with the hydrogeology of the region. The details of hydrogeology over the six lake locations are given in table 2. Over the alluvium and sandstone aquifer regions, a good match is evident, whereas over the crystalline aquifer regions, more lag and an inconsistent relationship was found. To the best of our knowledge, the recently released GRACE-GLDAS and GWSC are not validated against the satellite-derived altimetry water level heights in the India region.

\subsection{Interannual variations of GWSC and TWS}

Trends in TWS and GWSC in the annual, El Niño and La Nina periods are shown in figure 4 . The results show a remarkable decline of trend at a rate of $\sim 1.6 \mathrm{~cm} \mathrm{yr}^{-1}$ in northern India, particularly over places like Bihar, Delhi and Uttar Pradesh, whereas an increasing trend is seen over the southern India at a rate of $\sim 0.6 \mathrm{~cm} \mathrm{yr}^{-1}$. The declining water level can be due to the overextraction of ground water in north India mostly because of irrigation and other uses, and this is the most densely populated area in India. In addition, the long-term 

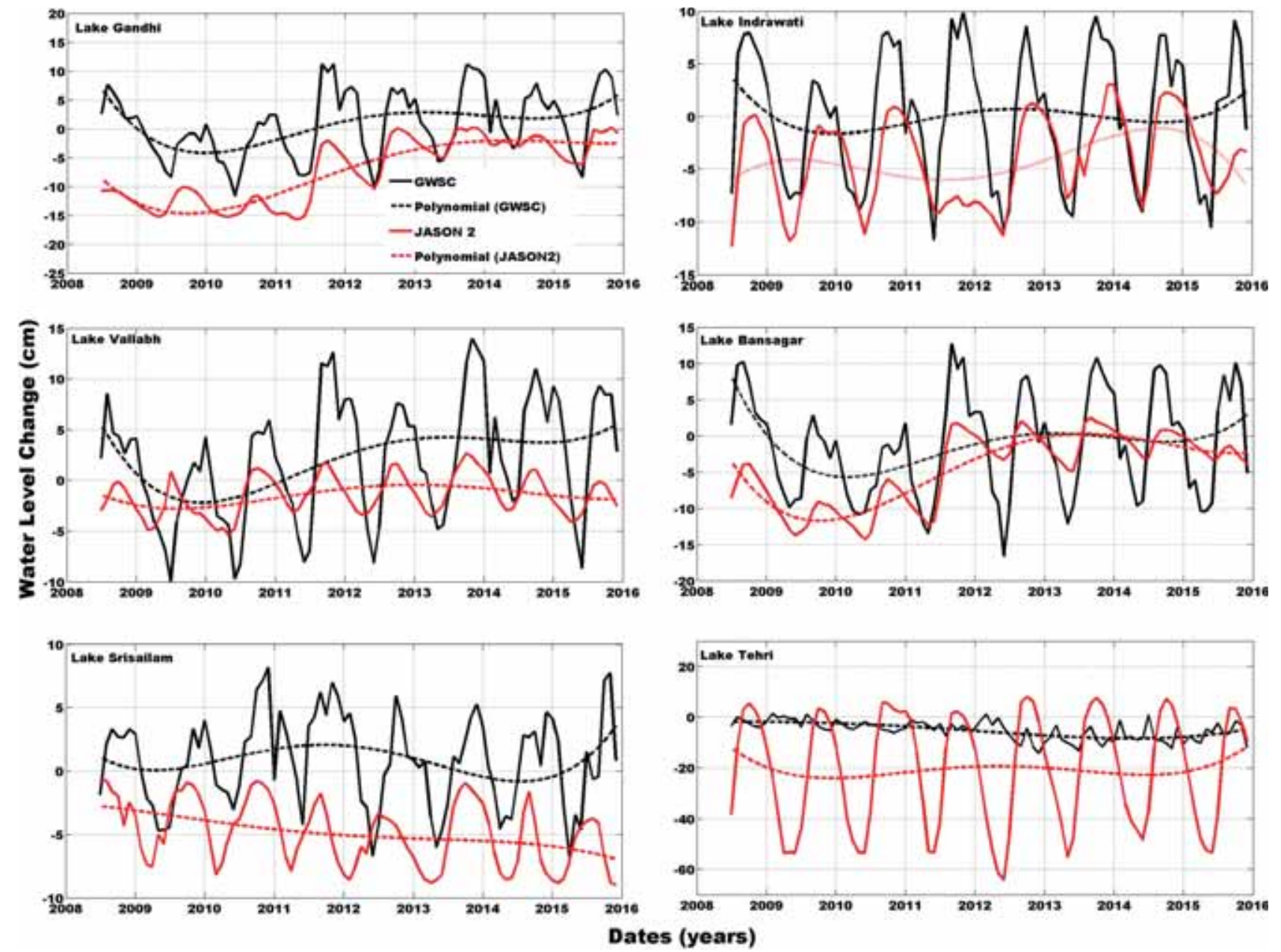

Figure 2. Cross plotting of GWSC and water-level changes over the six lakes.

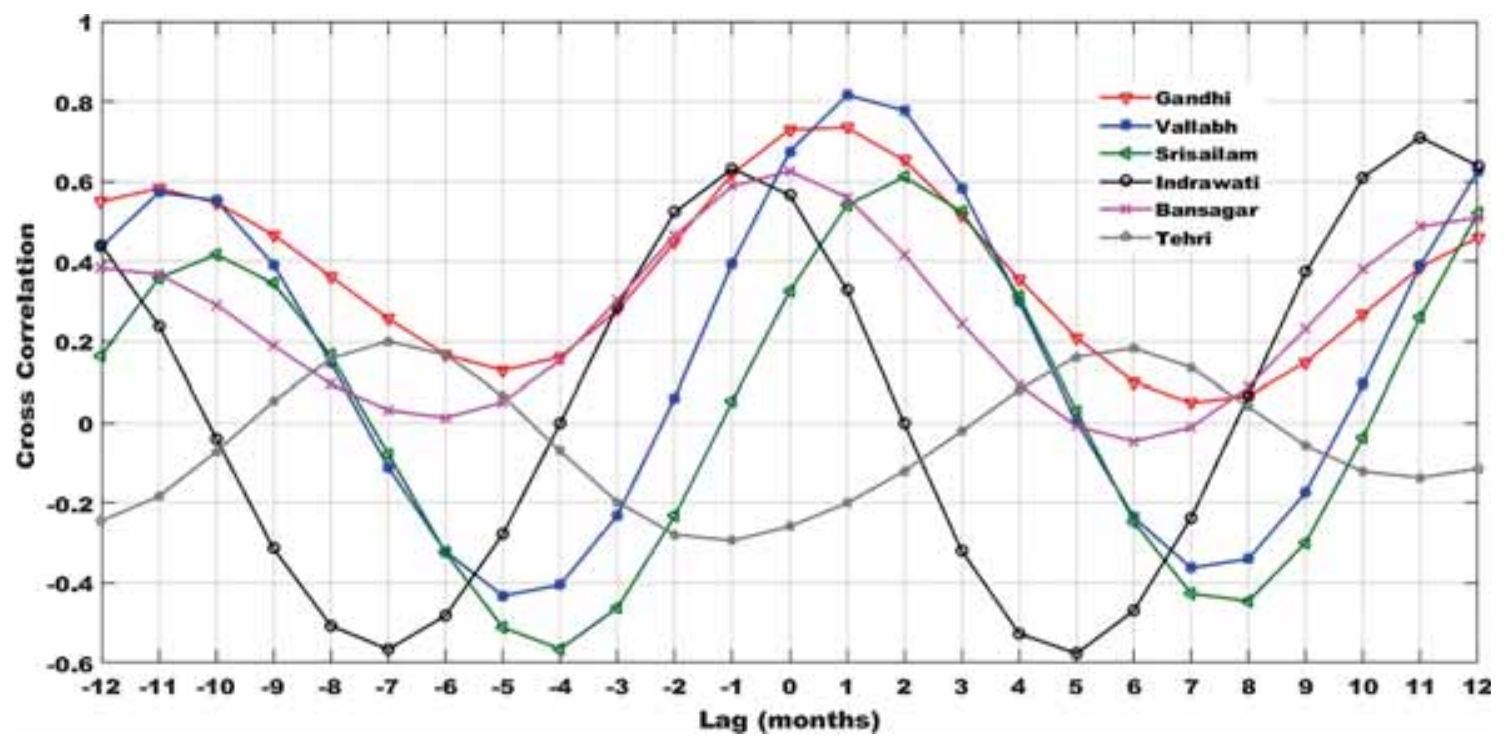

Figure 3. Spatial cross correlations between GWSC and water-level changes over the six lakes.

changes in precipitation can also influence the groundwater storage in India. The positive trends show that positive precipitation is higher in southern India and irrigation schemes (Asoka et al.
2017). A comparison of groundwater trend rates with the present study and earlier studies, which were estimated from GRACE, are shown in table 3 . 
Table 2. Hydrogeological information of the six lakes (reservoirs) in India.

\begin{tabular}{llllll}
\hline $\begin{array}{l}\text { Sl. } \\
\text { no. }\end{array}$ & $\begin{array}{l}\text { Lake } \\
\text { name }\end{array}$ & Position & \multicolumn{1}{c}{ State } & $\begin{array}{l}\text { River } \\
\text { basin }\end{array}$ \\
\hline 1 & Tehri & $30.5^{\circ} \mathrm{N}, 78.3^{\circ} \mathrm{E}$ & $\begin{array}{l}\text { Uttarakhand } \\
\text { Aquifer type }\end{array}$ \\
2 & Gandhi & $24.3^{\circ} \mathrm{N}, 75.3^{\circ} \mathrm{E}$ & Madhya Pradesh & Bhagirathi & Quartz, granite and granite genesis \\
3 & Bansagar & $24.0^{\circ} \mathrm{N}, 80.8^{\circ} \mathrm{E}$ & Madhya Pradesh & Sone & Alluvium \\
4 & Vallabh & $21.5^{\circ} \mathrm{N}, 74.1^{\circ} \mathrm{E}$ & Gujarat & Tapti & Alluvium and basalts \\
5 & Indrawati & $19.2^{\circ} \mathrm{N}, 82.8^{\circ} \mathrm{E}$ & Odisha & Indrawati & Granite and granite genesis \\
6 & Srisailam & $15.9^{\circ} \mathrm{N}, 78.4^{\circ} \mathrm{E}$ & Andhra Pradesh, Telangana & Krishna & Sandstone, shale, limestone and quartz \\
\hline
\end{tabular}
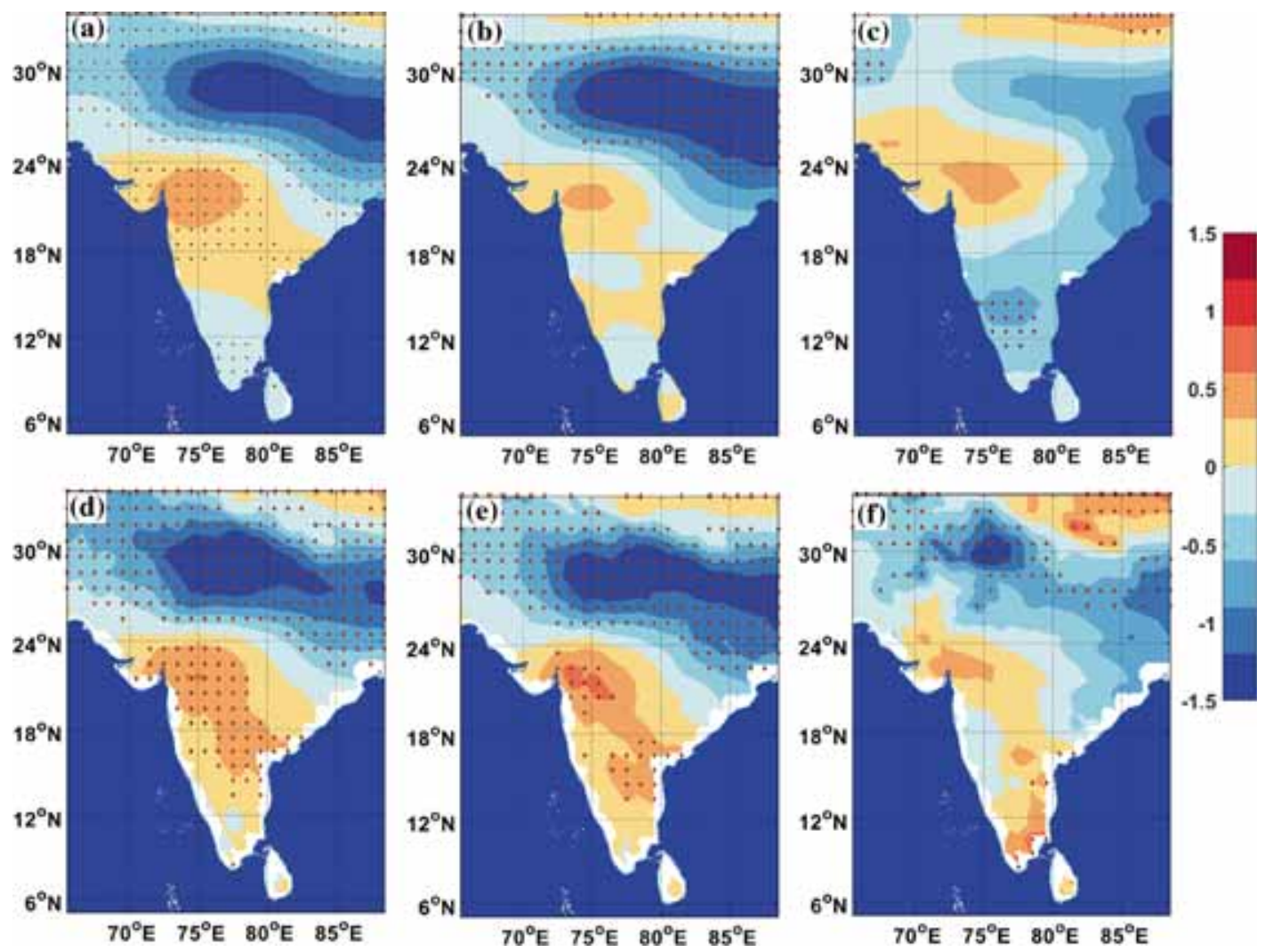

Figure 4. Trends in GWSC and TWS for the annual (a and $\mathbf{d})$, El Niño (b and e) and La Niña (c and f) periods. Circles denote regions of statistical significance at the $95 \%$ confidence level $(p<0.05)$.

Table 3. Comparison of GWSC rates with earlier studies.

\begin{tabular}{|c|c|c|c|c|}
\hline & Present work & $\begin{array}{c}\text { Asoka's analysis } \\
(2017)\end{array}$ & $\begin{array}{l}\text { Rodell's analysis } \\
\qquad(2009)\end{array}$ & $\begin{array}{c}\text { Tiwari's analysis } \\
(2009)\end{array}$ \\
\hline Observation period & $2003-2015$ & $2002-2013$ & $2002-2008$ & $2002-2008$ \\
\hline Water table trend (north India) & $\sim-1.67 \mathrm{~cm} \mathrm{yr}^{-1}$ & $\sim-2 \mathrm{~cm} \mathrm{yr}^{-1}$ & $\sim-4.0 \mathrm{~cm} \mathrm{yr}^{-1}$ & $\sim-54 \pm 9 \mathrm{~km}^{3} \mathrm{yr}^{-1}$ \\
\hline Water table trend (southern India) & $\sim 0.6 \mathrm{~cm} \mathrm{yr}^{-1}$ & $1-2 \mathrm{~cm} \mathrm{yr}^{-1}$ & - & - \\
\hline
\end{tabular}

During the El Niño period, the spatial extent of GWSC and TWS was widespread over the northern and eastern India regions. The depletion rate was much higher in north India which was already affected by overexploitation of groundwater. Over the southern India and western India $\left(\sim 75^{\circ} \mathrm{E}\right.$ and $22^{\circ} \mathrm{N}$ ) regions, a slight increasing trend of
GWSC is evident. During the El Niño years of the Indian summer, monsoon season rainfall and Pacific Ocean sea surface temperature anomalies are negatively correlated over the most homogeneous rainfall regions of India (Ashok et al. 2001; Ashok and Saji 2007; Gill et al. 2015). A recent study by Sinha et al. (2017) adopted 


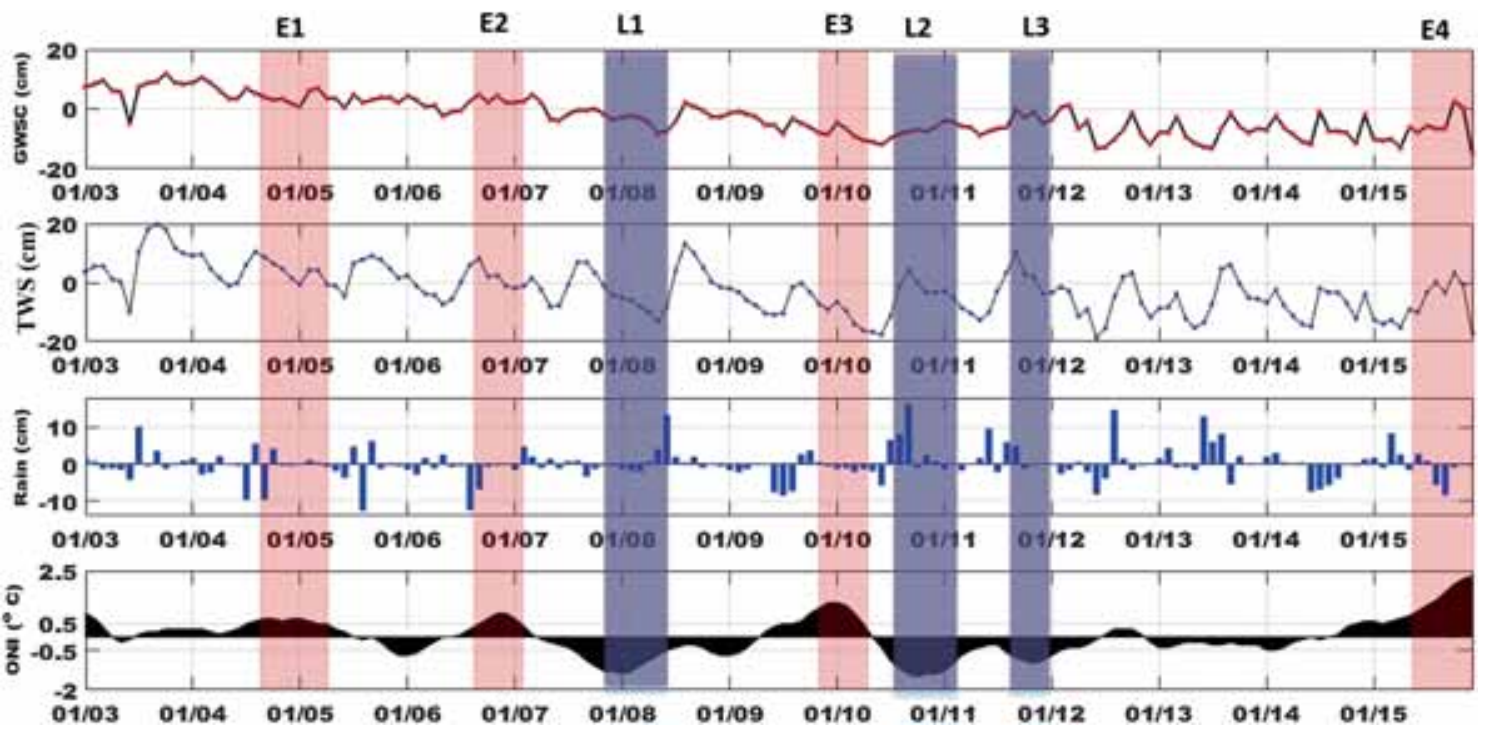

Figure 5. Monthly variation of GWSC, TWS, rainfall anomalies and ONI over the northern India region.

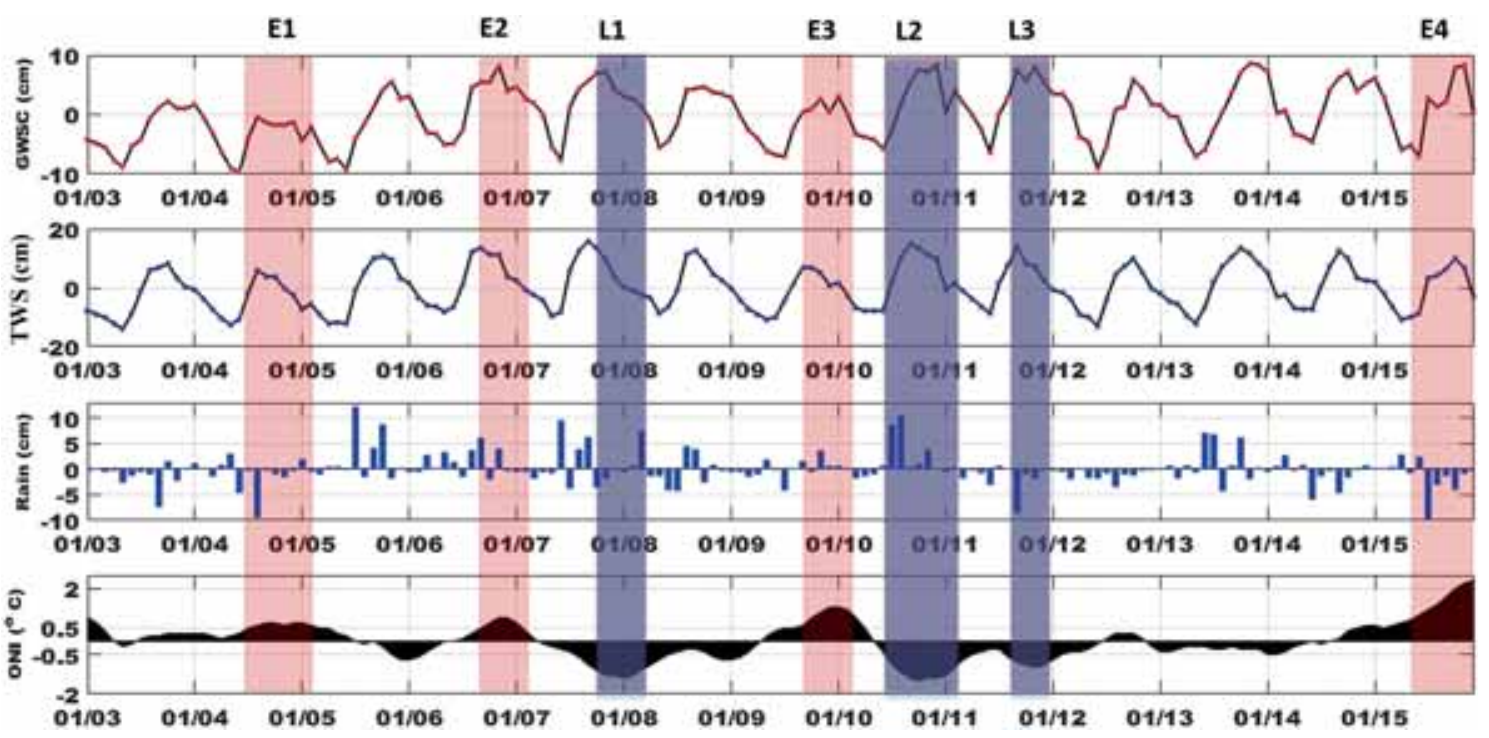

Figure 6. Same as figure 5 but for the southern Indian region.

the newly developed water storage deficit index to characterise drought over India from GRACE measurements for the period 2003-2015. Their findings revealed that during the years 20022004, 2009-2010 and 2012-2013, several parts of India experienced severe droughts. Results from the present study and the MK trend analysis during the El Niño years support the findings of Sinha et al. (2017). During the La Niña years, a weakening of groundwater depletion trends is evident over the northern parts of India, and this can be associated with the strengthening of India summer monsoon season and floods during the La Niña periods (Krishnan and Sugi 2003; Gill et al. 2015). A comparison of GWSC, TWS and rainfall anomalies over the northern $\left(74-82^{\circ} \mathrm{E}\right.$ and $\left.27-31^{\circ} \mathrm{N}\right)$ and southern $\left(74-79^{\circ} \mathrm{E}\right.$ and $\left.15-20^{\circ}\right)$ India regions with ONI (figures 5 and 6) is presented. Over northern India, major depletion of groundwater is evident over the years E2, E3 and E4, inconsistent with the rainfall anomalies over the region. During the periods of L1, L2 and L3, replenishment of groundwater is evident in concurrence with the rainfall anomalies. Over southern India, GWSC and rainfall anomalies are not as consistent in comparison with northern India. Our results demonstrate groundwater depletion over northern India and an increasing trend over southern India, inconsistent with previous studies (Asoka et al. 2017). However, this study provides an evidence of the impact of the ENSO on the GWSC, particularly over the northern India region. 


\section{Conclusions}

The interannual variation of groundwater was comprehended over India during period 2003-2015 using the gravimetric GRACE measurements and land surface model from GLDAS using the water balance equation. These obtained observations are validated by using the satellite altimetry data of selected lakes, water-level changes and then compared with the GWSC of these lakes. The 13-yr mean results discovered from gravimetric studies demonstrate a decline in water level at the rate of $1.6 \mathrm{~cm} \mathrm{yr}^{-1}$ over northern India and an increase in water level at the rate of $0.6 \mathrm{~cm} \mathrm{yr}^{-1}$ over southern India in both TWS and GWSC. The impact of ENSO on groundwater changes is evident over northern India. Future projections of Coupled Model Inter comparison Project phase 5 (CMIP5) models show an increased frequency of extreme El Niño (Cai et al. 2014a), positive Indian Ocean Dipole (pIOD) (Cai et al. 2014b) and La Niña (Cai et al. 2015) events under the greenhouse warming scenario. The unchecked rates of groundwater withdrawals under the global warming scenario would have profound implications on water resource management.

\section{Acknowledgements}

The authors would like to acknowledge various data portals such as the Central Ground Water Board (CGWB) India, Gravity Recovery and Climate Experiment (GRACE), Global Land Data Assimilation System (GLDAS), United States Department of Agriculture (USDA) and NOAA Global Precipitation Climatology Centre (GPCC). We are grateful to the editor and anonymous reviewers for their constructive comments and suggestions.

\section{References}

Almanaseer N and Sankarasubramanian A 2011 Role of climate variability in modulating the surface water and groundwater interaction over the southeast United States; J. Hydrol. Eng. 17 1001-1010, https://doi.org/10.1061/ (ASCE)HE.1943-5584.0000536.

Ashok K and Saji N H 2007 On the impacts of ENSO and Indian Ocean dipole events on sub-regional Indian summer monsoon rainfall; Nat. Hazards 42 273-285, https:// link.springer.com/article/10.1007/s11069-006-9091--0.

Ashok K, Guan Z and Yamagata T 2001 Impact of the Indian Ocean dipole on the relationship between the Indian monsoon rainfall and ENSO; Geophys. Res. Lett. 284499 4502, https://doi.org/10.1029/2001GL013294.
Asoka A, Gleeson T, Wada Y and Mishra V 2017 Relative contribution of monsoon precipitation and pumping to changes in groundwater storage in India; Nat. Geosci. 10 109-117, https://www.nature.com/articles/ ngeo2869.

Bettadpur S 2007 Product specification document, Rev 4.5; Grace, pp. 327-720.

Bhanja S N, Mukherjee A, Saha D, Velicogna I and Famiglietti J S 2016 Validation of GRACE based groundwater storage anomaly using in-situ groundwater level measurements in India; J. Hydrol. 543 729-738, https://doi.org/ 10.1016/j.jhydrol.2016.10.042.

Bhanja S N, Rodell M, Li B, Saha D and Mukherjee A 2017 Spatio-temporal variability of groundwater storage in India; J. Hydrol. 544 428-437, https://doi.org/10. 1016/j.jhydrol.2016.11.052.

Cai W, Borlace S, Lengaigne M, Van Rensch P, Collins M, Vecchi G, Timmermann A, Santoso A, McPhaden M J, Wu L and England M H 2014a Increasing frequency of extreme El Niño events due to greenhouse warming; Nat. Clim. Change 4 111-116, https://www.nature.com/ articles/nclimate2100.

Cai W, Santoso A, Wang G, Weller E, Wu L, Ashok K, Masumoto Y and Yamagata T 2014b Increased frequency of extreme Indian Ocean Dipole events due to greenhouse warming; Nature 510 254-258, https://www.nature.com/ articles/nature13327.

Cai W, Wang G, Santoso A, McPhaden M J, Wu L, Jin F F, Timmermann A, Collins M, Vecchi G, Lengaigne M and England M H 2015 Increased frequency of extreme La Nina events under greenhouse gas warming; Nat. Clim. Change 5 132, https://www.nature.com/articles/ nclimate2492.

Cao G and Zheng C 2016 Signals of short term climatic periodicities detected in the groundwater of North China Plain; Hydrol. Process. 30 515-533, https://doi.org/10. 1002/hyp.10631.

Chen J, Li J, Zhang Z and Ni S 2014 Long-term groundwater variations in Northwest India from satellite gravity measurements; Global Planet. Change 116 130-138, https:// doi.org/10.1016/j.gloplacha.2014.02.007.

Chinnasamy P, Hubbart J A and Agoramoorthy G 2013 Using remote sensing data to improve groundwater supply estimations in Gujarat, India; Earth Interact. 17 1-7, https://doi.org/10.1175/2012EI000456.1.

Devineni N and Sankarasubramanian A 2010 Improving the prediction of winter precipitation and temperature over the continental United States: Role of the ENSO state in developing multimodel combinations; Mon. Weather Rev. 138 2447-2468, https://doi.org/10.1175/ 2009MWR3112.1.

Ek M B, Mitchell K E, Lin Y, Rogers E, Grunmann P, Koren V, Gayno G and Tarpley J D 2003 Implementation of Noah land surface model advances in the National Centres for Environmental Prediction operational mesoscale Eta model; J. Geophys. Res. 108 GCP12, https://doi.org/10. 1029/2002JD003296.

Famiglietti J S 2014 The global groundwater crisis; Nat. Clim. Change 4 945, https://doi.org/10.1038/ nclimate2425.

Gill E C, Rajagopalan B and Molnar P 2015 Sub seasonal variations in spatial signatures of ENSO on the Indian 
summer monsoon from 1901 to 2009; J. Geophys. Res. 120 8165-8185, https://doi.org/10.1002/2015JD023184.

Girotto M, De Lannoy G J, Reichle R H, Rodell M, Draper C, Bhanja S N and Mukherjee A 2017 Benefits and pitfalls of GRACE data assimilation: A case study of terrestrial water storage depletion in India; Geophys. Res. Lett. 44 4107-4115, https://doi.org/10.1002/2017GL072994.

Han S C 2017 Elastic deformation of the Australian continent induced by seasonal water cycles and the 2010-2011 La Niña determined using GPS and GRACE; Geophys. Res. Lett. 44 2763-2772, https://doi.org/10.1002/ 2017 GL072999.

Katpatal Y B, Rishma C and Singh C K 2018 Sensitivity of the Gravity Recovery and Climate Experiment (GRACE) to the complexity of aquifer systems for monitoring of groundwater; Hydrogeol. J. 26 933-943, https://doi.org/ 10.1007/s10040-017-1686-x.

Krishnan R and Sugi M 2003 Pacific decadal oscillation and variability of the Indian summer monsoon rainfall; Clim. Dyn. 21(3-4) 233-242, https://doi.org/10.1007/ s00382-003-0330-8.

Krishnaswamy J, Vaidyanathan S, Rajagopalan B, Bonell M, Sankaran M, Bhalla R S and Badiger S 2015 Nonstationary and non-linear influence of ENSO and Indian Ocean Dipole on the variability of Indian monsoon rainfall and extreme rain events; Clim. Dyn. 45 175-184, https:// link.springer.com/article/10.1007/s00382-014-2288-0.

Kumar V, Jain S K and Singh Y 2010 Analysis of longterm rainfall trends in India; Hydrol. Sci. J. 55 484-496, https://doi.org/10.1080/02626667.2010.481373.

Kuss A J and Gurdak J J 2014 Groundwater level response in US principal aquifers to ENSO, NAO, PDO, and AMO; J. Hydrol. 519 1939-1952, https://doi.org/10. 1016/j.jhydrol.2014.09.069.

Lakshmi V 2016 Beyond GRACE using satellite data for groundwater investigations; Groundwater 54 615-618, https://doi.org/10.1111/gwat.12444.

Landerer F W and Swenson S C 2012 Accuracy of scaled GRACE terrestrial water storage estimates; Water Resour. Res. 48 W04531, https://doi.org/10.1029/ 2011WR011453.

Mann H B 1945 Nonparametric tests against trend; J. Econ. Soc. 13 245-259, https://www.jstor.org/stable/ pdf/1907187.pdf.

Mukherjee A and Ramachandran P 2018 Prediction of GWL with the help of GRACE TWS for unevenly spaced time series data in India: Analysis of comparative performances of SVR, ANN and LRM; J. Hydrol. 558 647-658, https:// doi.org/10.1016/j.jhydrol.2018.02.005.

Ni S, Chen J, Wilson C R, Li J, Hu X and Fu R 2018 Global terrestrial water storage changes and connections to ENSO events; Surv. Geophys. 39 1-22, https://doi.org/ 10.1007/s10712-017-9421-7.

Ouma Y O, Aballa D O, Marinda D O, Tateishi R and Hahn M 2015 Use of GRACE time-variable data and GLDASLSM for estimating groundwater storage variability at small basin scales: A case study of the Nzoia River basin; Int. J. Remote Sens. 36 5707-5736, https://doi.org/10. 1080/01431161.2015.1104743.
Panda D K and Wahr J 2016 Spatiotemporal evolution of water storage changes in India from the updated GRACE-derived gravity records; Water Resour. Res. 52 135-149, https://doi.org/10.1002/2015WR017797.

Richey A S, Thomas B F, Lo M H, Reager J T, Famiglietti J S, Voss K, Swenson S and Rodell M 2015 Quantifying renewable groundwater stress with GRACE; Water Resour. Res. 51 5217-5238, https://doi.org/10. 1002/2015WR017349.

Rodell M, Famiglietti J S, Chen J, Seneviratne S I, Viterbo P, Holl S and Wilson C R 2004 Basin scale estimates of evapotranspiration using GRACE and other observations; Geophys. Res. Lett. 31 L20504, https://doi.org/10.1029/ 2004GL020873.

Rodell M, Velicogna I and Famiglietti J S 2009 Satellitebased estimates of groundwater depletion in India; Nature 460 999-1002, https://www.nature.com/articles/ nature08238.

Rodell M, Famiglietti J S, Wiese D N, Reager J T, Beaudoing H K, Landerer F W and Lo M H 2018 Emerging trends in global freshwater availability; Nature $\mathbf{5 5 7}$ 651, https:// www.nature.com/articles/s41586-018-0123-1.

Russo T A and Lall U 2017 Depletion and response of deep groundwater to climate-induced pumping variability; Nat. Geosci. 10 105-108, https://www.nature.com/ articles/ngeo2883.

Sen P K 1968 Estimates of the regression coefficient based on Kendall's tau; J. Am. Stat. Assoc. 631379 1389, https://amstat.tandfonline.com/doi/abs/10.1080/ 01621459.1968.10480934.

Sinha D, Syed T H, Famiglietti J S, Reager J T and Thomas R C 2017 Characterizing drought in India using GRACE observations of terrestrial water storage deficit; J. Hydrometeorol. 18 381-396, https://doi.org/10.1175/ JHM-D-16-0047.1.

Swenson S, Wahr J and Milly P C 2003 Estimated accuracies of regional water storage variations inferred from the gravity recovery and climate experiment (GRACE); Water Resour. Res. 39 SWC 11, https://doi.org/10. 1029/2002WR001808.

Swenson S, Yeh P J, Wahr J and Famiglietti J 2006 A comparison of terrestrial water storage variations from GRACE with in-situ measurements from Illinois; Geophys. Res. Lett. 33 L16401, https://doi.org/10.1029/ 2006GL026962.

Taylor R G, Scanlon B, Döll P, Rodell M, Van Beek R, Wada Y, Longuevergne L, Leblanc M, Famiglietti J S, Edmunds M and Konikow L 2013a Ground water and climate change; Nat. Clim. Change 3 322-329, https:// www.nature.com/articles/nclimate1744.

Taylor R G, Todd M C, Kongola L, Maurice L, Nahozya E, Sanga H and Mac Donald A M 2013b Evidence of the dependence of groundwater resources on extreme rainfall in east Africa; Nat. Clim. Change 3 374-378, https:// www.nature.com/articles/nclimate1731.

Tiwari V M, Wahr J and Swenson S 2009 Dwindling groundwater resources in northern India, from satellite gravity observations; Geophys. Res. Lett 36 L18401, https://doi. org/10.1029/2009GL039401. 